\title{
Pengaruh Alkali Aktif terhadap Karakteristik Pulp Kraft Putih Acacia mangium dan Eucalyptus pellita
}

\author{
Teddy Kardiansyah*, Susi Sugesty \\ Balai Besar Pulp dan Kertas, Jl. Raya Dayeuhkolot No. 132, Bandung, Indonesia \\ Diterima : 21 April 2020, Revisi akhir : 21 Juni 2020, Disetujui terbit : 30 Juni 2020 \\ Effect of Active Alkali on Characteristic of Acacia mangium and Eucalyptus pellita \\ Bleached Kraft Pulp
}

\begin{abstract}
The Indonesian pulp industry currently has problems in supplying Acacia mangium wood raw materials, due to plant disease and pest attacks. This could be anticipated through alternative raw materials to substitute Acacia mangium, the Eucalyptus pellita species chosen because it is more resistant to pests and diseases. This study was conducted to determine the quality characteristics of E. pellita bleached kraft pulp. The research on making paper pulp using A. mangium and E. pellita was carried out by means of the kraft process. The cooking was carried out with a variation of $16-20 \%$ active alkali, $28.7 \%$ sulfidity, at a temperature of $165^{\circ} \mathrm{C}$, a liquor to wood ratio of 3.5:1 and an H factor of 1,022. The bleaching of the pulp has been carried out using the Elemental Chlorine Free (ECF) process with the $O D_{0} E_{O} D_{I}$ stage. Characteristics of kraft pulp from A. mangium cooking were higher in the screening yield, kappa number, and viscosity compared to E. pellita. The use of $16 \%$ active alkaline in cooking of A. mangium is lower than E. pellita (18\%), but the quality can meet the quality specifications according to SNI 6107: 2015 - Leaf Bleached Kraft Pulp on the parameters of freeness, brightness and physical properties. The characteristics of A. mangium bleached kraft pulp were higher in parameters of freeness, brightness and physical properties compared to E. pellita. However, E. pellita has the potential to be developed in Industrial Plantation Forests as raw material for pulp.
\end{abstract}

Keywords: Acacia mangium, active alkali, Eucalyptus pellita, kraft, pulp

\begin{abstract}
Abstrak
Industri pulp Indonesia saat ini memiliki masalah dalam penyediaan bahan baku kayu Acacia mangium, karena serangan penyakit tanaman dan hama. Hal ini harus diantisipasi melalui bahan baku alternatif pengganti Acacia mangium, spesies Eucalyptus pellita dipilih karena lebih tahan terhadap hama dan penyakit. Penelitian ini dilakukan untuk mengetahui karakteristik kualitas pulp kraft putih E. pellita. Penelitian pembuatan pulp kertas dilakukan dengan proses kraft dengan bahan baku A. mangium dan E. pellita. Pemasakan dilakukan dengan variasi alkali aktif $16-20 \%$, sulfiditas $28,7 \%$, pada suhu $165^{\circ} \mathrm{C}$, rasio larutan pemasak terhadap kayu 3,5:1 dan faktor $\mathrm{H}$ 1.022. Pemutihan pulp dilakukan dengan proses Elemental Chlorine Free (ECF) dengan tahapan $\mathrm{OD}_{0} \mathrm{E}_{0} \mathrm{D}_{1}$. Karakteristik pulp kraft hasil pemasakan A. mangium lebih tinggi pada parameter rendemen tersaring, bilangan kappa dan viskositas dibandingkan dengan E. pellita. Penggunaan alkali aktif $16 \%$ pada pemasakan A. mangium lebih rendah dari E. pellita (18\%), namun kualitasnya dapat memenuhi spesifikasi kualitas pulp sesuai SNI 6107:2015 - Pulp Kraft Putih Kayudaun pada parameter derajat giling, derajat cerah, dan sifat fisik. Karakteristik pulp kraft putih A. mangium lebih tinggi pada parameter derajat giling, derajat cerah, dan sifat fisik dibandingkan dengan E. pellita. Namun demikian E. pellita berpotensi untuk dikembangkan di Hutan Tanaman Industri sebagai bahan baku pulp.
\end{abstract}

Kata kunci: Acacia mangium, alkali aktif, Eucalyptus pellita, kraft, pulp 


\section{Pendahuluan}

Kapasitas produksi pulp di Indonesia meningkat pada tahun 2017 karena kehadiran pabrik baru. Kapasitas produksi pulp yang sebelumnya 7,9 juta ton per tahun meningkat menjadi 10,5 juta ton per tahun. Kapasitas produksi pulp tersebut setidaknya memerlukan bahan baku kayu sekitar 41,4 juta ton kayu per tahun (Nambiar, Harwood and Mendham, 2018). Kebutuhan kayu tersebut dipenuhi melalui tegakan yang ditanam oleh Hutan Tanaman Industri (HTI) yang umumnya menanam jenis akasia dan ekaliptus. Spesies akasia ditanam secara luas di Asia Tenggara dengan luas tanaman lebih dari 2,6 juta hektar (Harwood and Nambiar, 2014).

Di Indonesia, A. mangium telah menjadi spesies kayu untuk pulp yang mendominasi selama 10 tahun terakhir sebagai sumber serat yang sangat baik untuk pembuatan kertas (Muhammad, Ong and Ratnam, 2018; Hillman, 2002). Hutan Tanaman Industri untuk bahan baku pulp di Indonesia mengembangkan jenis A. mangium Willd dan A. crassicarpa A. Cunn (Suhartati,Rahmayanto and Daeng, 2014). Tanaman tersebut ditanam di hutan tanaman industri (HTI) dengan penanaman monokultur. Monokultur memiliki keunggulan dalam kemudahan penebangan dan perawatan, namun bila kawasan monokultur terserang penyakit, dalam waktu relatif cepat semua tanaman akan rusak. Pada tahun 2001 dilaporkan bahwa tegakan monokultur A. mangium rotasi kedua di Sumatera telah mengalami kerusakan antara 3-28\% akibat serangan ganoderma (Irianto et al., 2006). Kanker batang-layu yang disebabkan oleh Ceratocystis manginecans sp. nov. (Tarigan et al., 2011) di Sumatra dan Kalimantan. Serangan kera dan tupai menguliti batang A. mangium untuk mengambil exudate yang manis, serangannya mencapai sekitar 100.000 ha di Sumatera dan 30.000 ha di Kalimantan (Hardiyanto and Nambiar, 2014; Nambiar, Harwood and Mendham, 2018).

Masalah serangan pada kayu di tanah mineral tersebut sangat serius dan tidak dapat diantisipasi oleh industri, sehingga menyebabkan pergantian penanaman spesies yang sangat cepat dari $A$. mangium menjadi Eucalyptus pellita F. Muell dan hibridanya. Laju pergantiannya mencapai 50.000 ha/tahun dan pada tahun 2016-2017 sebanyak 600.000 ha lahan sudah ditanami E. pellita yang sebelumnya A. mangium (Nambiar, Harwood and Mendham, 2018). Pemilihan spesies E. pellita sebagai pengganti disebabkan oleh beberapa faktor, diantaranya: karena sifatnya yang cepat tumbuh, rotasi pendek, batang lurus, toleransi yang tinggi terhadap berbagai jenis tanah dan lokasi tumbuh serta lebih tahan terhadap hama dan penyakit (Lukmandaru et al., 2016). Namun demikian produktivitas $E$. pellita masih rendah dibandingkan dengan A. mangium. Produktivitas pohon pada umur 3-6 tahun untuk $A$. mangium sekitar $42,2 \mathrm{~m}^{3} / \mathrm{ha} /$ tahun sedangkan $E$. pellita hanya sekitar 39,6 $\mathrm{m}^{3} /$ ha/tahun (Mendham et al., 2017).

Proses pembuatan pulp kraft merupakan proses yang umum digunakan industri pulp di Indonesia dengan kelebihan lainnya yaitu menghasilkan pulp dengan kekuatan tinggi, efisien pada banyak jenis kayu, toleran terhadap kulit kayu, serta efisien dalam siklus pemulihan bahan kimia (Shmulsky and Jones, 2011). Penelitian sebelumnya pemasakan A. mangium dan $E$. pellita dengan variasi alkali aktif $16-20 \%$, sulfiditas 25\% dengan Faktor H 800 dan tanpa diputihkan dengan parameter indikator bilangan Kappa, rendemen dan viskositas (Ardina, Irawan and Prajitno, 2018). Pada penelitian ini dilakukan proses pembuatan pulp kraft dari A. mangium dan E. pellita dengan variasi alkali aktif dan dilanjutkan dengan proses pemutihan menggunakan proses Elemental Chlorine Free (ECF). Pulp kraft putih yang diperoleh selanjutnya diuji kualitas pulpnya.

\section{Bahan dan Metode}

\section{Bahan}

Bahan baku yang digunakan dalam penelitian ini adalah serpih kayu Acacia mangium dan Eucalyptus pellita yang diperoleh dari Industri Pulp di daerah Sumatera Selatan. Serpih kayu tersebut dipasok dari Hutan Tanaman Industri yang sedang mengembangkan penanaman kayu Eucalyptus pellita sebagi pengganti Acacia mangium. Natrium hidroksida dan natrium sulfida kualitas teknis diperoleh dari pemasok bahan kimia lokal. Bahan kimia untuk proses pemutihan yang terdiri dari natrium klorit dari JT Baker dan natrium peroksidisulfat diperoleh dari Merck. Bahan kimia untuk analisis bilangan Kappa dan viskositas kualitas analisis diperoleh dari Merck. 


\section{Metode}

Tahapan penelitian meliputi pemasakan bahan baku, pemutihan pulp proses Elemental Chlorine Free (ECF) dengan empat tahapan, pembuatan lembaran pulp putih dan penentuan sifat fisik dan optik pulp putih. Pemasakan kayu Acacia mangium dan Eucalyptus pellita dilakukan dengan proses sulfat (kraft) dalam digester berputar (rotary digester) dalam udara panas dengan suhu yang dapat dikontrol menggunakan perhitungan faktor $\mathrm{H}$ (Tabel 1). Faktor $\mathrm{H}$ merupakan faktor hubungan antara suhu dengan waktu, apabila suhu tinggi waktu yang digunakan menjadi pendek. Pulp yang diperoleh ditentukan rendemen total, rendemen tersaring, bilangan Kappa (SNI ISO 302:2014), viskositas pulp (SNI 0936:2008) serta derajat cerah (SNI ISO 24701:2014).

Pemutihan pulp dilakukan dengan tahapan oksigen delignifikasi, klordioksida awal, ekstraksi oksigen dan klordioksida-1 $\left(\mathrm{OD}_{0} \mathrm{E}_{0} \mathrm{D}_{1}\right)$. Kondisi proses pemutihan pulp dapat dilihat pada Tabel 2. Parameter kontrol pada setiap tahapan pemutihan ditentukan meliputi viskositas dan derajat cerah serta bilangan kappa pada tahapan oksigen delignifikasi dan ekstraksi oksigen. Pulp putih yang diperoleh ditentukan sifat optik dan sifat fisiknya. Untuk pengujian sifat fisik, pulp digiling dalam PFI Mill (SNI ISO 5264-2:2011). Variasi derajat giling ditentukan berdasarkan jumlah putaran PFI Mill yang diukur dengan menggunakan Canadian Standard Freeness Tester (CSF), kemudian dibuat lembaran (SNI ISO 5269-1:2012) selanjutnya dilakukan pengujian sifat fisik lembaran pulp menurut SNI yang terdiri dari indeks sobek (SNI 0436-2009), indeks retak (SNI ISO 2758:2011), indeks tarik (SNI ISO 14-4737:1998) serta sifat optik yaitu derajat cerah dengan SNI ISO 2470-1:2014.

Tabel 1. Kondisi Pembuatan Pulp Proses Kraft

\begin{tabular}{clc}
\hline No. & Parameter & $\begin{array}{c}\text { Kondisi } \\
\text { Pemasakan }\end{array}$ \\
\hline 1 & Suhu, ${ }^{\circ} \mathrm{C}$ & 165 \\
2 & Rasio larutan pemasak & $3,5: 1$ \\
& terhadap kayu & \\
3 & Sulfiditas, \% & 28,7 \\
4 & Alkali aktif, \% & $16 \%, 18 \%, 20 \%$ \\
5 & Faktor H & 1.022 \\
6 & Waktu, jam & $2+1$ \\
\hline
\end{tabular}

Tabel 2. Kondisi Proses Pemutihan Pulp

\begin{tabular}{lcccc}
\hline Parameter & $\mathrm{O}$ & $\mathrm{D}_{0}$ & Eo & $\mathrm{D}_{1}$ \\
\hline Suhu, ${ }^{\circ} \mathrm{C}$ & 90 & 70 & 84 & 85 \\
$\begin{array}{l}\text { Konsistensi, } \\
\%\end{array}$ & 11 & 11 & 11 & 11 \\
$\begin{array}{l}\text { Waktu reaksi, } \\
\text { menit }\end{array}$ & 30 & 45 & 90 & 180 \\
$\mathrm{ClO}_{2}, \%$ & - & 3,5 & - & 1,5 \\
$\begin{array}{l}\text { Tekanan } \mathrm{O}_{2}, \\
\text { Psi }\end{array}$ & 50 & - & 150 & - \\
$\begin{array}{l}\text { NaOH, } \% \\
\text { pH Akhir }\end{array}$ & 1 & - & 1,1 & - \\
\hline
\end{tabular}

\section{Hasil dan Pembahasan}

\section{Pemasakan Kayu A.mangium dan E. pellita}

Parameter kendali setelah proses pemasakan meliputi rendemen total, rendemen tersaring, dan bilangan kappa. Selain itu juga sebagai parameter pendukung ditentukan viskositas dan derajat cerah pulp hasil pemasakan untuk evaluasi proses selanjutnya. Hasil pemasakan kayu A.mangium dan E. Pellita dapat dilihat pada Tabel 3.

Rendemen total pulp merupakan gabungan dari rendemen tersaring dan reject. Rendemen total maupun rendemen tersaring pulp $A$. mangium lebih tinggi dibandingkan pulp E. pellita pada berbagai konsentrasi alkali aktif. Nilai tersebut juga termasuk dalam nilai rendemen tersaring pulp sulfat kayu daun lebar yang berkisar antara 40-55\% (Shmulsky and Jones, 2011). Nilai rendemen tersebut lebih rendah dibandingkan dengan rendemen $A$. crassicarpa yang berkisar antara 52,65-53,61\% (Sugesty, Kardiansyah and Pratiwi, 2015) dan A. mangium serta E. pellita hasil penelitian lain yaitu $52,25 \%$ dan $50,60 \%$ (Ardina, Irawan and Prajitno, 2018). Namun nilai rendemen tersebut lebih tinggi dibandingkan dengan $A$. mangium dari Malaysia dengan rendemen 37,60-23,20\% (Wan Rosli, Mazlan and Law, 2009).

Peningkatan konsentrasi alkali aktif cenderung menurunkan nilai rendemen tersaring baik untuk pulp $A$. mangium maupun E. pellita. Hasil ini sesuai dengan penelitian A. crassicarpa (Sugesty, Kardiansyah and Pratiwi, 2015) dan Anthocephalus cadamba (Wistara et al., 2015). MacLeod (2007) mengkuantifikasi pengaruh peningkatan dosis alkali terhadap penurunan rendemen pulp, setiap peningkatan $1 \%$ alkali aktif akan menurunkan rendemen pulp $0,15 \%$, dan 
Tabel 3. Hasil Pemasakan Kayu A. mangium dan E. pellita

\begin{tabular}{llcccccc}
\hline No & Jenis Pulp & $\begin{array}{c}\text { Alkali aktif } \\
(\%)\end{array}$ & $\begin{array}{c}\text { Rendemen } \\
\text { total (\%) }\end{array}$ & $\begin{array}{c}\text { Rendemen } \\
\text { tersaring }(\%)\end{array}$ & $\begin{array}{c}\text { Bilangan } \\
\text { Kappa }\end{array}$ & $\begin{array}{c}\text { Viskositas } \\
(\mathrm{cP})\end{array}$ & $\begin{array}{c}\text { Derajat cerah } \\
(\% \text { ISO) }\end{array}$ \\
\hline \multirow{3}{*}{1} & \multirow{2}{*}{ A. mangium } & 16 & 51,37 & 51,23 & 17,60 & 20,14 & 35,56 \\
& 18 & 50,20 & 50,12 & 14,50 & 15,78 & 37,37 \\
& & 20 & 49,10 & 49,05 & 12,73 & 13,45 & 39,27 \\
\hline \multirow{2}{*}{2} & \multirow{2}{*}{ E. pellita } & 16 & 47,85 & 47,77 & 16,13 & 18,24 & 34,05 \\
& 18 & 47,16 & 47,08 & 14,32 & 14,98 & 35,14 \\
& 20 & 46,50 & 46,41 & 11,50 & 11,91 & 36,39 \\
\hline
\end{tabular}

lebih tinggi pada kasus kayu daun lebar karena tingginya kandungan hemiselulosa sehingga rentan terhadap alkali.

Bilangan kappa merupakan nilai yang menunjukkan tingkat kematangan pulp. Bilangan Kappa A. mangium dan E. pellita menurun seiring dengan meningkatnya konsentrasi alkali aktif. Peningkatan konsentrasi alkali aktif pada proses pembuatan pulp akan menurunkan nilai bilangan Kappa karena tingginya tingkat kehilangan lignin selama proses (Bassa et al., 2006). Rentang nilai bilangan kappa sebesar 12,73-17,60 untuk A. mangium dan sebesar 11,50-16,13 untuk $E$. pellita. Nilai bilangan kappa sekitar 15-20 untuk kayu daun lebar menunjukkan pulp tersebut termasuk mudah diputihkan (Gellerstedt, Ek and Henriksson, 2009). Nilai bilangan kappa A. mangium cenderung lebih tinggi dibandingkan dengan $E$. pellita, pola tersebut sejalan dengan penelitian yang dilakukan oleh Ardina, Irawan dan Prajitno (2018).

Viskositas pulp belum putih umumnya ditentukan sebagai dasar pemrosesan pulp berikutnya. Viskositas pulp dapat mewakili derajat polimerisasi selulosa dalam pulp (Wistara et al., 2015). Viskositas pulp belum putih $A$. mangium maupun E. pellita cenderung turun dengan peningkatan konsentrasi alkali aktif. Penurunan viskositas pulp belum putih dapat disebabkan oleh peningkatan konsentrasi ion hidroksida dalam larutan pemasak. Ion hidroksida tidak hanya menurunkan lignin, tetapi pada konsentrasi yang lebih tinggi dapat menurunkan kadar selulosa. Degradasi selulosa oleh alkali dapat berlangsung melalui reaksi pengelupasan dan hidrolisis alkali yang menyebabkan penurunan viskositas pulp (Shukla and Sharma, 2013). Viskositas pulp belum putih A. mangium $(13,45-20,14 \mathrm{cP})$ cenderung lebih tinggi dibandingkan dengan pulp belum putih
E. pellita $(11,91-18,24 \mathrm{cP})$, pada dosis alkali aktif 16\%-18\% kecenderungannya sama dengan penelitian yang dilakukan oleh Ardina, Irawan dan Prajitno (2018). Hal ini menunjukkan bahwa A. mangium cenderung lebih tahan terhadap reaksi pengelupasan (peeling) dan hidrolisis alkali dibandingkan dengan $E$. pellita.

Derajat cerah pulp belum putih adalah indikator yang berguna untuk melihat kemampuan pulp dapat diputihkan. Derajat cerah pulp belum putih A. mangium sekitar 35,56-39,27\%ISO, lebih tinggi jika dibandingkan dengan derajat cerah pulp belum putih $E$. pellita dengan kisaran $34,05-36,39 \%$ ISO. Nilai derajat cerah pulp belum putih menunjukkan penurunan dengan meningkatnya konsentrasi alkali aktif. Peningkatan derajat cerah terutama disebabkan oleh penghilangan lignin selama proses pembuatan pulp (Wistara et al., 2015).

\section{Pemutihan Pulp A. mangium dan E. pellita}

Bilangan kappa selain sebagai parameter indikator proses pemasakan, bilangan kappa dapat memperkirakan kandungan lignin sisa dalam pulp dan dapat digunakan untuk menentukan kondisi pemutihan yang sesuai (Sugesty, Kardiansyah and Pratiwi, 2015). Nilai bilangan kappa pada tahapan proses pemutihan pulp dapat dilihat pada

\section{Gambar 1.}

Nilai bilangan kappa brownstock pulp $A$. mangium cenderung lebih tinggi dibandingkan E. pellita, setelah melalui proses pemutihan menunjukkan nilai bilangan kappa yang hampir sama dengan kondisi pemutihan yang sama. Proses pemutihan menggunakan klorin dioksida senyawa tersebut mendegradasi lignin pada struktur fenoliknya sedangkan reaksi dengan lignin non-fenolik dan asam hekseuronat berjalan lamban (Eshkiki, Mortha and Lachenal, 2007). 


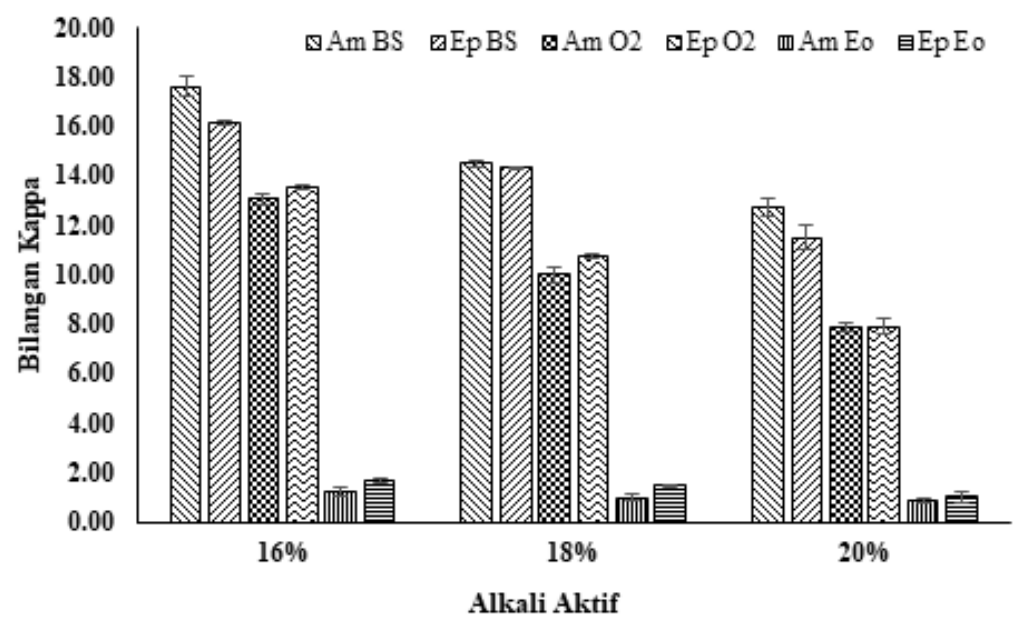

Gambar 1. Bilangan Kappa Pulp pada Brownstock (BS), Tahap Delignifikasi Oksigen (O2) dan Tahap Ekstraksi Oksigen (Eo). Keterangan Am (A. mangium) dan Ep (E. pellita)

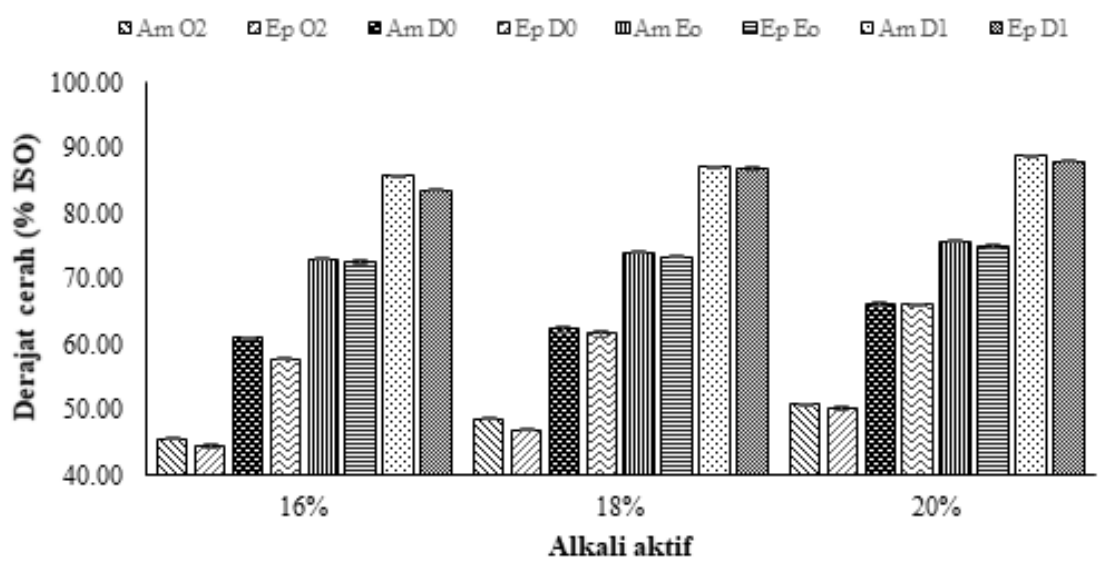

Gambar 2. Derajat Cerah Pulp pada Tahap Delignifikasi Oksigen (O2), Tahap Klordioksida Awal (D0), Tahap Ekstraksi Oksigen (Eo) dan Tahap Klordioksida 1 (D1). Keterangan Am (A. mangium) dan Ep (E. pellita)

Bilangan kappa merupakan representasi dari kadar lignin dalam pulp. Nilai bilangan kappa pulp setelah tahap delignifikasi oksigen untuk A. mangium sekitar 7,88-13,05 sedangkan E. pellita bekisar antara 7,90-13,52 dengan persentase penurunan 25,85-38,09\% untuk A. mangium dan $16,16-31,30 \%$ untuk E. pellita.

Persentase penurunan bilangan kappa semakin tinggi setelah tahap $\mathrm{D}_{1}$ dengan rentang penurunan sekitar 93,10-93,39\% untuk A. mangium dan 89,51-91,19\% untuk E. pellita. Sifat dan kelimpahan relatif dari hubungan antara unit Syringil dan Guaiacyl (rasio $\mathrm{S} / \mathrm{G}$ ) dalam lignin sangat bervariasi, proporsi relatifnya mempengaruhi reaktivitas lignin selama proses pembuatan pulp dan pemutihan (Sjostrom, 1993).
Lignin dengan kandungan syringyl yang lebih tinggi cenderung lebih mudah untuk dihilangkan (Nawawi et al., 2017).

Derajat cerah merupakan sifat pantulan sinar biru pada panjang gelombang $457 \mathrm{~nm}$ dari lembaran pulp dan merupakan parameter indikator proses pemutihan pulp (Suess, 2010). Derajat cerah pulp A. mangium maupun E. pellita semakin meningkat dengan peningkatan konsentrasi alkali aktif, pola yang sama terjadi pada proses pemutihan pulp dari Trema orientalis (Sarwar Jahan, Rubaiyat and Sabina, 2007) dan jute (Matin et al., 2015). Nilai derajat cerah pada tahapan proses pemutihan pulp dapat dilihat pada Gambar 2. Peningkatan nilai derajat cerah dari pulp belum putih menjadi pulp putih lebih dari 


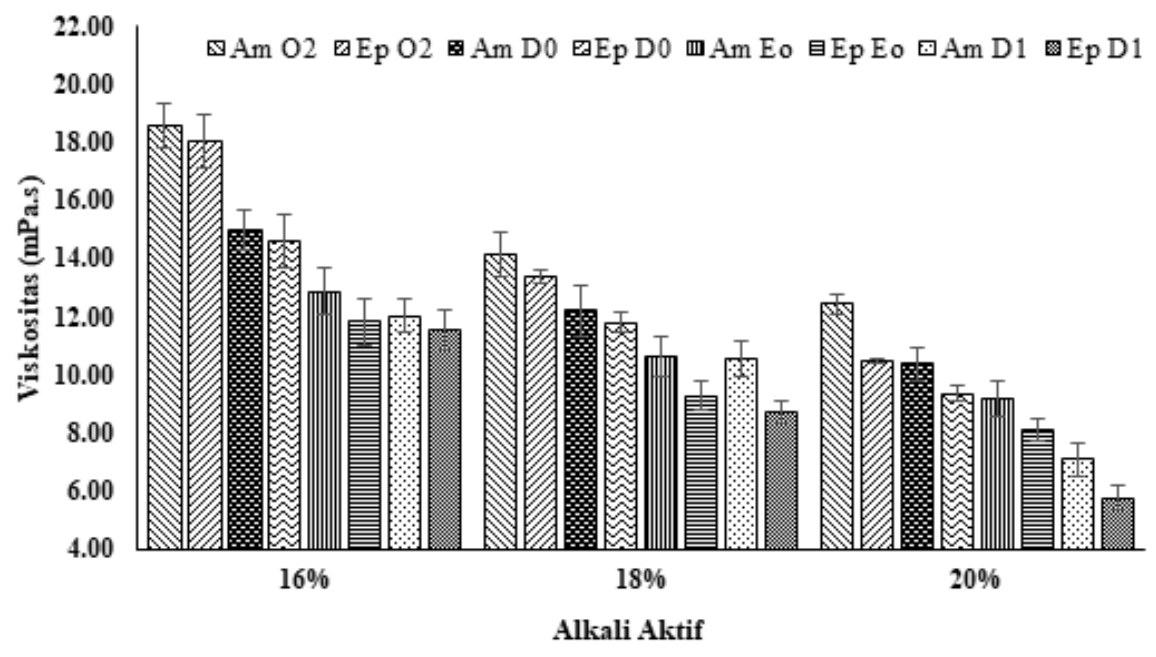

Gambar 3. Viskositas Pulp pada Tahap Delignifikasi Oksigen (O2), Tahap Klordioksida Awal (D0), tahap ekstraksi oksigen (Eo) dan Tahap Klordioksida 1 (D1). Keterangan Am (A. mangium) dan Ep (E. pellita)

dua kali lipat dengan kisaran 35,56-39,27\%ISO menjadi 85,80-88,93\%ISO untuk A. mangium dan 34,05-36,39\%ISO menjadi 83,53-87,93\%ISO untuk E. pellita. Peningkatan nilai derajat cerah pulp melalui pemutihan dengan klorin dioksida tidak hanya secara efisien melarutkan sisa fragmen lignin, tetapi juga mengurangi gugus kromoforik dalam pulp, dan mengurangi kapasitas lignin dalam pulp untuk menyerap cahaya (Gullichsen, Fogelholm and Paulapuro, 1999).

Viskositas pulp dapat mewakili derajat polimerisasi selulosa dalam pulp (Wistara et al., 2015). Parameter tersebut merupakan salah satu parameter kontrol dalam proses pemutihan. Nilai viskositas pada tahapan proses pemutihan pulp dapat dilihat pada Gambar 3.

Nilai viskositas pulp A. mangium cenderung lebih tinggi dibandingkan E. pellita, pulp A. mangium cenderung lebih tahan terhadap proses pemutihan dibandingkan dengan E. pellita. Nilai viskositas pulp setelah tahap delignifikasi oksigen untuk $A$. mangium sekitar 12,44-18,60 cP sedangkan E. pellita bekisar antara 10,46-18,05 cP dengan persentase penurunan 7,51-10,55\% untuk A. mangium dan 10,78-12,14\% untuk $E$. pellita. Persentase penurunan viskositas semakin tinggi setelah tahap $\mathrm{D}_{1}$ dengan rentang penurunan sekitar 33,12-47,29\% untuk A. mangium dan $36,72-51,70 \%$ untuk E. pellita. Penurunan nilai viskositas pulp setelah proses pemutihan dengan proses ECF sekitar 21,8\% hingga 25,7 \% untuk bambu (Li et al., 2018) dan sekitar 71,03\% dari E. globulus (Colodette et al.,
1999). Viskositas pulp putih dapat memberikan indikasi tidak langsung dari kekuatan pulp. Pulp dengan viskositas tinggi cenderung menunjukkan sifat mekanik yang lebih baik (Khiari et al., 2010).

\section{Derajat Giling (Freeness)}

Derajat giling pulp adalah kemampuan pulp untuk melepaskan air dalam suspensi pulp. Sifat ini terkait dengan karakteristik permukaan serat pulp dan pembengkakan serat. Parameter ini juga berpengaruh dalam aliran proses pulp dan proses pembuatan kertas wet-end (Wistara et al., 2015).

Nilai derajat giling pulp sebelum dan setelah digiling dalam PFI Mill dapat dilihat pada Gambar 4. Nilai derajat giling pulp A. mangium cenderung lebih rendah dibandingkan E. pellita, derajat giling pulp A. mangium sekitar 570-590 mLCSF sedangkan E. pellita sekitar 630-640 mLCSF. Derajat giling yang tinggi cenderung memerlukan energi yang lebih besar untuk menurunkan nilai derajat gilingnya agar laju penghilangan airnya sesuai dengan target yang diharapkan (Buzała et al., 2018). Pulp A. mangium memerlukan jumlah putaran sekitar 4.900-5.200 dan E. pellita sekitar 5.200-5.300 untuk mencapai nilai derajat giling yang sama (300 mL CSF). Karakteristik lain seperti indeks tarik dan indeks retak diketahui memiliki korelasi linear dengan derajat giling pulp (Banavath, Bhardwaj and Ray, 2011). 


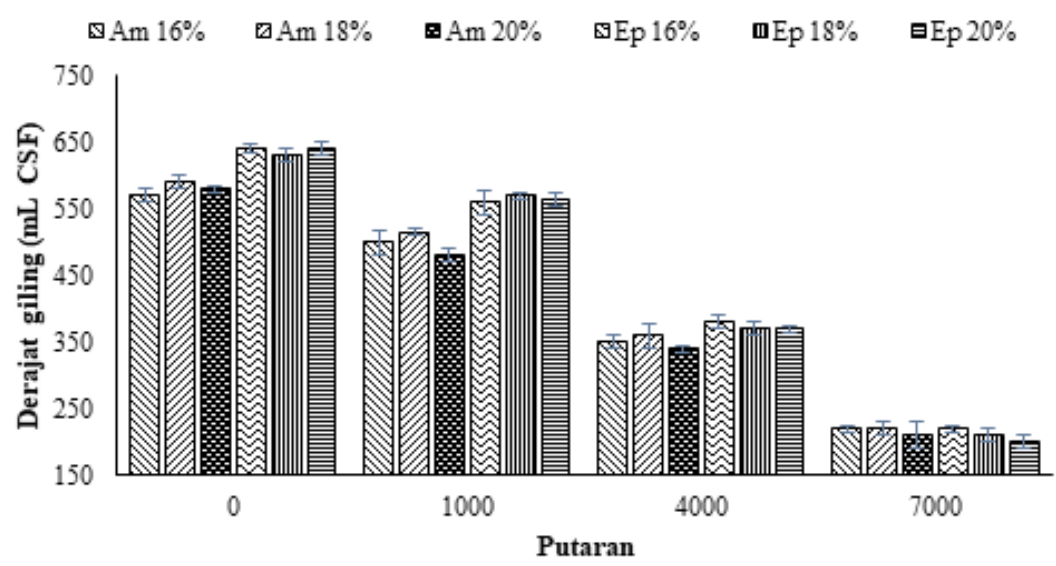

Gambar 4. Derajat Giling Pulp pada Variasi Konsentrasi Alkali Aktif terhadap Jumlah Putaran PFI Mill. Keterangan Am (A. mangium) dan Ep (E. pellita)

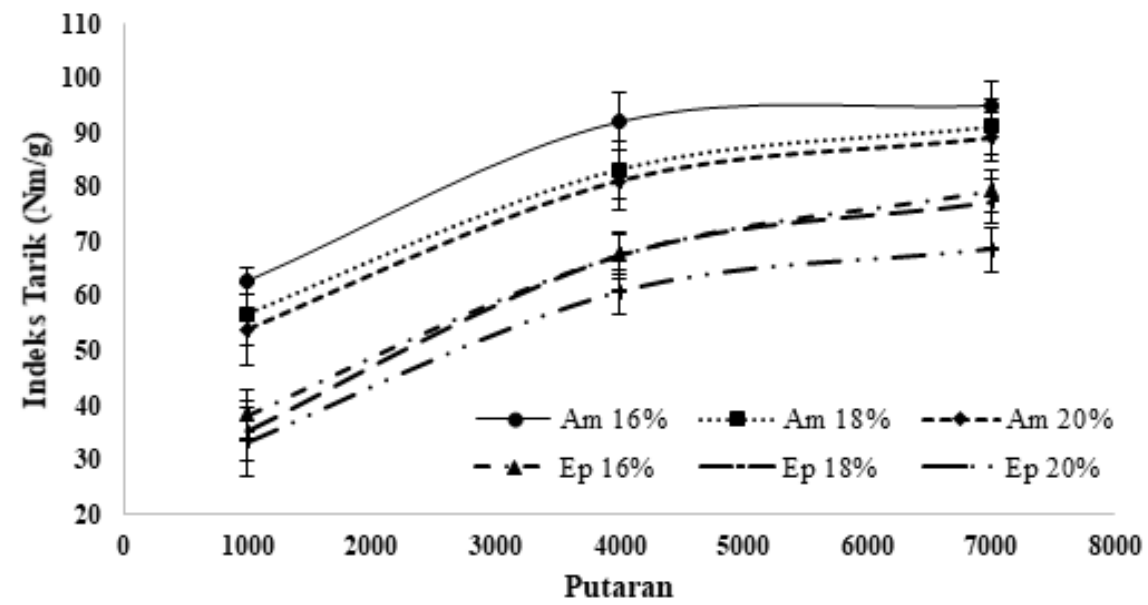

Gambar 5. Indeks Tarik Pulp pada Variasi Konsentrasi Alkali Aktif terhadap Jumlah Putaran PFI Mill. Keterangan Am (A. mangium) dan Ep (E. pellita)

\section{Sifat Fisik Pulp Putih}

Pengujian sifat fisik pulp putih yang dilakukan dalam penelitian ini meliputi pengujian indeks retak, indeks tarik, dan indeks sobek. Penggilingan pulp mengacu pada perlakuan mekanis pada serat pulp untuk meningkatkan sifat fisik pulp pada pembuatan kertasnya (Abdel-aal, 2014).

Hasil pengukuran indeks tarik dapat dilihat pada Gambar 5. Indeks tarik pulp $A$. mangium berada pada rentang $22,5-95,1 \mathrm{Nm} / \mathrm{g}$ sedangkan pulp E. pellita berada pada rentang $13,7-79,4 \mathrm{Nm} / \mathrm{g}$. Indeks tarik pulp A. mangium dan $E$. pellita menunjukkan kecenderungan yang sama, semakin tinggi jumlah putaran PFI mill, nilai indeks tarik semakin meningkat. Proses penggilingan akan menyebabkan dinding serat collapse membentuk lembaran yang padat dan kekuatan tarik yang tinggi disebabkan rasio permukaan serat terhadap volume serat yang tinggi dan luas ikatan antar serat yang tinggi (Patt, Kordsachia and Fehr, 2006).

Selain itu dengan peningkatan alkali aktif nilai indeks tarik semakin menurun baik pada pulp A. mangium maupun E. pellita, hal ini sesuai dengan dengan menurunnya nilai viskositas pulp dengan meningkatnya dosis alkali aktif. Penurunan tersebut disebabkan degradasi selulosa dengan meningkatnya dosis alkali aktif. Selama proses pembuatan pulp, alkali akan melarutkan rantai hemiselulosa berat molekul rendah, memulai reaksi depolimerisasi akhir (reaksi pengelupasan primer), dan hidrolisis dari ikatan glikosidik, yang menyebabkan reaksi 


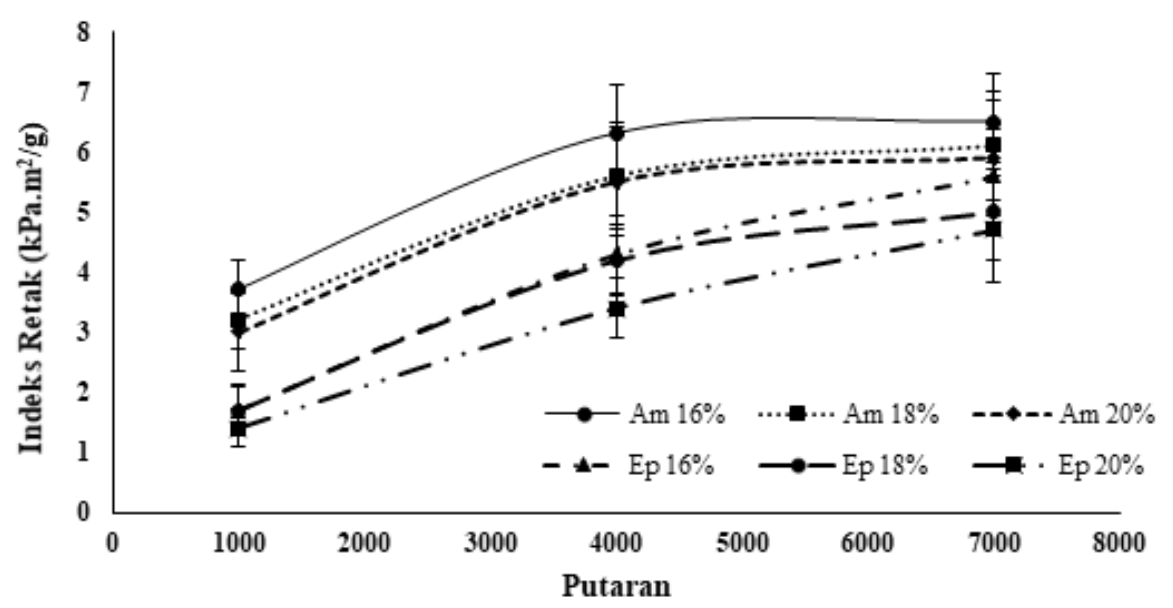

Gambar 6. Indeks Retak Pulp pada Variasi Konsentrasi Alkali Aktif terhadap Jumlah Putaran PFI Mill. Keterangan Am (A. mangium) dan Ep (E. pellita)

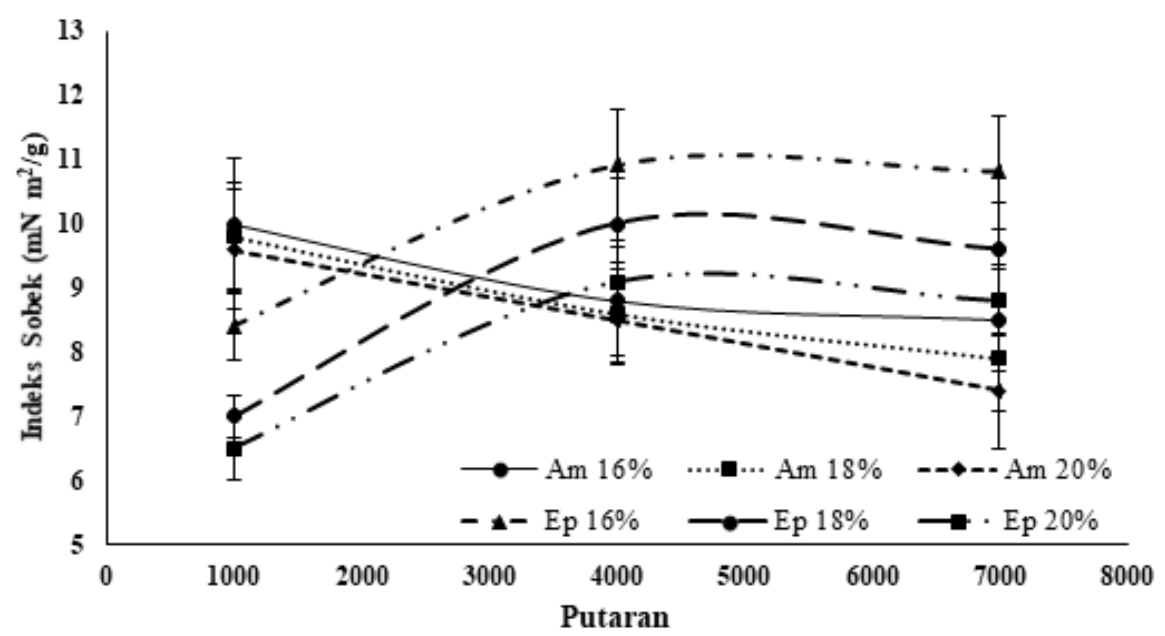

Gambar 7. Indeks Sobek Pulp pada Variasi Konsentrasi Alkali Aktif terhadap Jumlah Putaran PFI Mill. Keterangan Am (A. mangium) dan Ep (E. pellita)

pengelupasan sekunder dan penurunan derajat polimerisasi (Bajpai, 2018). Nilai indeks tarik sangat dipengaruhi oleh faktor alkali aktif (Wan Rosli, Mazlan and Law, 2009).

Indeks retak diuji untuk mengetahui nilai kekuatan pulp untuk menahan beban yang terpusat (Shmulsky and Jones, 2011). Hasil pengukuran indeks retak dapat dilihat pada Gambar 6. Indeks retak pulp $A$. mangium berada pada kisaran 0,9-6,5 $\mathrm{kPa} \cdot \mathrm{m}^{2} / \mathrm{g}$ sedangkan pulp E. pellita berada pada rentang $0,5-5,6 \mathrm{kPa} \cdot \mathrm{m}^{2} / \mathrm{g}$. Indeks retak menunjukkan pola yang sama dengan indeks tarik baik terhadap pengaruh penggilingan dan alkali aktif.

Ketahanan sobek diperlukan untuk mengetahui ketahanan kertas terhadap gaya sobek selama konversi atau pemakaian kertas akhir (Scott and Trosset, 1989). Hasil pengukuran indeks sobek dapat dilihat pada Gambar 7. Indeks sobek pulp A. mangium berada pada rentang 5,6-10 $\mathrm{mN} \cdot \mathrm{m}^{2} / \mathrm{g}$ sedangkan pulp E. pellita berada pada rentang 2,1-10,9 $\mathrm{mN} \cdot \mathrm{m}^{2} / \mathrm{g}$. Pola penggilingan terhadap indeks sobek pulp A. mangium dan E. pellita memiliki kecenderungan yang sama, dimana peningkatan putaran penggilingan meningkat hingga putaran tertentu selanjutnya menurun, sehingga memiliki titik maksimum. Pulp A. mangium menurun pada putaran sekitar 1.000 dan E. pellita pada putaran 4.000 .

\section{Kualitas Pulp Putih}

Kualitas pulp A. mangium dan E. pellita dibandingkan dengan spesifikasi pulp kraft putih kayu daun lebar berdasarkan SNI dapat dilihat 
Tabel 4. Sifat Optik dan Sifat Fisik Pulp Kraft Putih A. mangium dan E. pellita

\begin{tabular}{|c|c|c|c|c|c|c|c|}
\hline \multirow{2}{*}{ No. } & \multirow{2}{*}{ Jenis Pulp } & \multirow{2}{*}{ Parameter } & \multirow{2}{*}{ Satuan } & \multirow{2}{*}{$\begin{array}{c}\text { SNI } \\
6107: 2015\end{array}$} & \multicolumn{3}{|c|}{ Konsentrasi Alkali Aktif } \\
\hline & & & & & $16 \%$ & $18 \%$ & $20 \%$ \\
\hline \multirow{5}{*}{1} & \multirow{5}{*}{ A. mangium } & Derajat giling awal & $\mathrm{mL} \mathrm{CSF}$ & 430 & 570 & 590 & 580 \\
\hline & & Derajat cerah ISO & $\%$ ISO & 85 & 85,80 & 87,06 & 88,93 \\
\hline & & $\begin{array}{l}\text { Indeks sobek pada derajat } \\
\text { giling } 300 \mathrm{~mL} \text { CSF }\end{array}$ & $\mathrm{mN} \mathrm{m}^{2} / \mathrm{g}$ & 5,5 & 8,67 & 8,33 & 8,16 \\
\hline & & $\begin{array}{l}\text { Indeks retak pada derajat } \\
\text { giling } 300 \mathrm{~mL} \text { CSF }\end{array}$ & $\mathrm{kPa} \mathrm{m}^{2} / \mathrm{g}$ & 2,5 & 6,38 & 5,73 & 5,68 \\
\hline & & $\begin{array}{l}\text { Indeks tarik pada derajat } \\
\text { giling } 300 \mathrm{~mL} \text { CSF }\end{array}$ & $\mathrm{Nm} / \mathrm{g}$ & 45 & 93,25 & 85,7 & 84,69 \\
\hline \multirow{5}{*}{2} & \multirow{5}{*}{ E. pellita } & Derajat giling awal & $\mathrm{mL} \mathrm{CSF}$ & 430 & 640 & 630 & 640 \\
\hline & & Derajat cerah ISO & $\%$ ISO & 85 & 83,53 & 86,93 & 87,93 \\
\hline & & $\begin{array}{l}\text { Indeks sobek pada derajat } \\
\text { giling } 300 \mathrm{~mL} \text { CSF }\end{array}$ & $\mathrm{mN} \mathrm{m}^{2} / \mathrm{g}$ & 5,5 & 10,85 & 9,83 & 8,98 \\
\hline & & $\begin{array}{l}\text { Indeks retak pada derajat } \\
\text { giling } 300 \mathrm{~mL} \text { CSF }\end{array}$ & $\mathrm{kPa} \mathrm{m}^{2} / \mathrm{g}$ & 2,5 & 4,95 & 4,55 & 3,94 \\
\hline & & $\begin{array}{l}\text { Indeks tarik pada derajat } \\
\text { giling } 300 \mathrm{~mL} \text { CSF }\end{array}$ & $\mathrm{Nm} / \mathrm{g}$ & 45 & 73,00 & 71,89 & 64,00 \\
\hline
\end{tabular}

pada Tabel 4. Secara umum kualitas pulp putih A. mangium dan E. pellita memenuhi parameter derajat giling awal, sifat fisik dan sifat optik. Namun demikian pulp putih $A$. mangium memiliki sifat yang lebih baik dibandingkan dengan pulp E. pellita, tetapi sifat fisik pulp putih E. pellita lebih baik dibandingkan A. crassicarpa (Sugesty, Kardiansyah and Pratiwi, 2015). Selain itu, dosis alkali aktif $16 \%$ untuk $A$. mangium sudah dapat memenuhi kualitas SNI, sedangkan E. pellita pada dosis alkali aktif tersebut tidak memenuhi parameter derajat cerah pulp sesuai SNI.

\section{Kesimpulan}

Karakteristik pulp kraft hasil pemasakan A. mangium lebih tinggi pada parameter rendemen tersaring, bilangan kappa dan viskositas dibandingkan dengan E. pellita. Penggunaan alkali aktif $16 \%$ pada $A$. mangium dapat memenuhi kualitas pulp kraft putih sesuai SNI pada parameter derajat giling, derajat cerah dan sifat fisik, sedangkan E. pellita memerlukan alkali aktif lebih tinggi yaitu $18 \%$. Karakteristik pulp kraft putih A. mangium lebih tinggi pada parameter derajat giling, derajat cerah dan sifat fisik dibandingkan dengan $E$. pellita. Namun demikian E. pellita berpotensi untuk dikembangkan di Hutan Tanaman Industri sebagai bahan baku pulp, karena lebih tahan terhadap hama dan penyakit tanaman dibandingkan dengan A. mangium. Tanaman E. pellita masih perlu dikembangkan melalui pemuliaan tanaman agar diperoleh klon dengan kualitas yang unggul, baik dari segi pertumbuhan maupun dari kualitas pulp yang dihasilkannya.

\section{Ucapan Terima Kasih}

Terima kasih disampaikan kepada Dimas Ryenki Prawira dan Ferengki Wahyudi atas bantuan dan dukungannya dalam pelaksanaan penelitian ini. Ucapan terima kasih juga disampaikan kepada PT. Tanjungenim Lestari Pulp and Paper atas penyediaan bahan baku dan sarana penelitian.

\section{Daftar Pustaka}

Abdel-aal, M. A. (2014) 'Effect of Cooking Time, Active Alkali Concentration and Refining Process on the Pulping and Papermaking Properties of Buttonwood Residues (Conocarpus erectus L.)', World Applied Sciences Journal, 27(1), pp. 1-9. doi: 10.5829/idosi.wasj.2013.27.01.13600.

Ardina, V., Irawan, B. and Prajitno, D. H. (2018) 'Active alkali charge effect on kraft pulping process of Acacia mangium and Eucalyptus pellita', in AIP Conference Proceedings, $\mathrm{p}$. 020036. doi: 10.1063/1.5054440. 
Bajpai, P. (2018) Biermann's Handbook of Pulp and Paper, Biermann's Handbook of Pulp and Paper. doi: 10.1016/c2017$0-00530-x$.

Banavath, H. N., Bhardwaj, N. K. and Ray, A. K. (2011) 'A comparative study of the effect of refining on charge of various pulps', Bioresource Technology. Elsevier Ltd, 102(6), pp. 4544-4551. doi: 10.1016/j. biortech.2010.12.109.

Bassa, A. G. M. C., Sanches Duarte, F. A., Da Silva, F. G. and Sacon, V. M. (2006) 'The effect of alkali charge on Eucalyptus spp. kraft pulping', 2006 TAPPI Engineering, Pulping and Environmental Conference Proceedings, 2006(June 2016).

Buzała, K. P., Kalinowska, H., Borkowski, J. and Przybysz, P.(2018) 'Effect of xylanases on refining process and kraft pulp properties', Cellulose, 25(2), pp. 1319-1328. doi: 10.1007/s10570-017-1609-y.

Colodette, J. L., Gomide, J. L., Argyropoulos, D. S., Robles, Y. A. M., Almeida, J. M., Mehlman, S. K. and DeBrito, A. G. H. (1999) 'Effect of pulping processses on bleachability with ECF, Z-ECF and TCF bleaching', Appita Journal, 52(5), pp. 368374.

Eshkiki, R. B., Mortha, G. and Lachenal, D. (2007) 'A new method for the titration of free phenolic groups in pulps', Holzforschung, 61(3), pp. 242-246. doi: 10.1515/ hf.2007.039.

Gellerstedt, G., Ek, M. and Henriksson, G. (2009) Wood chemistry and biotechnology, Wood Chemistry and Biotechnology. doi: 10.1515/9783110213409.

Gullichsen, J., Fogelholm, C.-J. and Paulapuro, H. (1999) 'Papermaking Science and Technology', in Gullichsen, J., Fogelholm, C.-J., and Paulapuro, H. (eds) Chemical Pulping. Fapet Oy.

Hardiyanto, E. B. and Sadanandan Nambiar, E. K. (2014) 'Productivity of successive rotations of Acacia mangium plantations in Sumatra, Indonesia: Impacts of harvest and inter-rotation site management', New Forests, 45(4), pp. 557-575. doi: 10.1007/ s11056-014-9418-8.

Harwood, C. E. and Nambiar, E. K. S. (2014) 'Productivity of Acacia and Eucalypt plantations in Southeast Asia. 2. Trends and variations', International Forestry Review, 16(2), pp. 249-260. doi: $10.1505 / 146554814811724766$.

Hillman, D. C. (2002) 'Single Species Pulping : The World's Preferred Market Pulps': Solutions, (November), pp. 27-30.
Irianto, R. S. B., Barry, K., Hidayati, N., Ito, S., Fiani, A., Rimbawanto, A. and Mohammed, C. (2006) 'Incidence and spatial analysis of root rot of Acacia mangium in Indonesia', Journal of Tropical Forest Science, 18(3), pp. 157-165.

Islam, M. N. (2004) 'Effect of chemical charges in cooking and their effectiveness on pulp bleaching', Journal of Scientific and Industrial Research, 63(6), pp. 522-526.

Jahan, M. S., Sabina, R. and Rubaiyat, A. (2008) 'Alkaline pulping and bleaching of Acacia auriculiformis grown in Bangladesh', Turkish Journal of Agriculture and Forestry, 32(4), pp. 339-347. doi: 10.3906/tar-0708-10.

Khiari, R., Mhenni, M. F., Belgacem, M. N. and Mauret, E. (2010) 'Chemical composition and pulping of date palm rachis and Posidonia oceanica - A comparison with other wood and non-wood fibre sources', Bioresource Technology. Elsevier Ltd, 101(2), pp. 775780. doi: 10.1016/j.biortech.2009.08.079.

Li, P., Hou, Q., Zhang, M. and Li, X. (2018) 'Environmentally Friendly Bleaching on Bamboo ( Neosinocalamus ) Kraft Pulp Cooked by Displacement Digester System', BioResources, 13(1), pp. 450-461.

Lukmandaru, G., Zumaini, U. F., Soeprijadi, D., Nugroho, W. D. and Susanto, M. (2016) 'Chemical Properties and Fiber Dimension of Eucalyptus pellita from The 2nd Generation of Progeny Tests in Pelaihari, South Borneo, Indonesia', Journal Korean Wood Science and Technology, 44(August), pp. 571-588. doi: 10.5658/WOOD.2016.44.4.571.

MacLeod, M. (2007) 'The top ten factors in kraft pulp yield', Paperi Ja Puu/Paper \& Timber, 89(4), pp. 3-7. Available at: http:// kraftpulpingcourse.knowledgefirstwebsites. com/f/Top_Ten.pdf.

Matin, M., Rahaman, M. M., Nayeem, J., Sarkar, M. and Jahan, M. S. (2015) 'Dissolving pulp from jute stick', Carbohydrate Polymers. Elsevier Ltd., 115, pp. 44-48. doi: 10.1016/j. carbpol.2014.08.090.

Mendham, D. S., Hardiyanto, E. B., Wicaksono, A. and Nurudin, M. (2017) 'Nutrient management of contrasting Acacia mangium genotypes and weed management strategies in South Sumatra, Indonesia', Australian Forestry. Taylor \& Francis, 80(3), pp. 127 134. doi: $10.1080 / 00049158.2017 .1331701$.

Muhammad,A. J., Ong, S. S. and Ratnam, W.(2018) 'Characterization of mean stem density, fibre length and lignin from two Acacia species and their hybrid', Journal of Forestry Research. Springer Berlin Heidelberg, 29(2), pp. 549555. doi: 10.1007/s11676-017-0465-9. 
Nambiar, E. K. S., Harwood, C. E. and Mendham, D. S. (2018) 'Paths to sustainable wood supply to the pulp and paper industry in Indonesia after diseases have forced a change of species from Acacia to Eucalypts', Australian Forestry. Taylor \& Francis, 81(3), pp. 148-161. doi: 10.1080/00049158.2018.1482798.

Nawawi, D. S., Syafii, W., Tomoda, I., Uchida, Y., Yokoyama, T. and Matsumoto, Y. (2017) 'Characteristics and reactivity of lignin in Acacia and Eucalyptus woods', Journal of Wood Chemistry and Technology. Taylor \& Francis, 0(0), pp. 1-10. doi: 10.1080/02773813.2017.1291684.

Patt, R., Kordsachia, O. and Fehr, J. (2006) 'European hardwoods versus Eucalyptus globulus as a raw material for pulping', Wood Science and Technology, 40(1), pp. 39-48. doi: 10.1007/s00226-005-0042-9.

Sarwar Jahan, M., Rubaiyat, A. and Sabina, R. (2007) 'Evaluation of cooking processes for Trema orientalis pulping', Journal of Scientific and Industrial Research, 66(10), pp. 853-859.

Scott, W. E. and Trosset, S. (1989) Properties of Paper: An Introduction. TAPPI Press.

Shmulsky, R. and Jones, P. D. (2011) Forest Products and Wood Science An Introduction: Sixth Edition, Forest Products and Wood Science An Introduction: Sixth Edition. doi: 10.1002/9780470960035.

Shukla, R. N. and Sharma, M. (2013) 'Impact of Cooking Conditions on Pulp Viscosity And Kappa Number of Leucaena Leucocephala Wood for Kraft Pulping', 2(3), pp. 1-10.
Sjostrom, E. (1993) Wood chemistry, fundamentals and applications, Carbohydrate Research. doi: 10.1016/0008-6215(94)90030-2.

Suess, H. U. (2010) Pulp bleaching today, Pulp Bleaching Today. doi: 10.1515/9783110218244.

Sugesty, S., Kardiansyah, T. and Pratiwi, W. (2015) 'Potensi Acacia crassicarpa sebagai Bahan Baku Pulp Kertas untuk Hutan Tanaman Industri', pp. 21-32.

Suhartati, Y. Rahmayanto, Y. D. (2014) 'Dampak Penurunan Daur Tanaman HTI Acacia terhadap Kelestarian Produksi, Ekologis dan Sosial', Info Teknis Eboni, 11(2), pp. 103116.

Tarigan, M., Roux, J., Van Wyk, M., Tjahjono, B. and Wingfield, M. J. (2011) 'A new wilt and die-back disease of Acacia mangium associated with Ceratocystis manginecans and C. acaciivora sp. nov. in Indonesia', South African Journal of Botany. SAAB, 77(2), pp. 292-304. doi: 10.1016/j.sajb.2010.08.006.

Wan Rosli, W., Mazlan, I. and Law, K. (2009) 'Effects of Kraft Pulping Variables on Pulp and Paper Properties of Acacia Mangium Kraft Pulp', Cellulose Chemistry and Technology, 43(1-3), pp. 9-15. Available at: http://www.cellulosechemtechnol.ro/pdf/ CCT1-3-2009/p.9-15.pdf.

Wistara, N. J. et al. (2015) 'Effect of tree age and active alkali on kraft pulping of White Jabon', Journal of the Korean Wood Science and Technology, 43(5), pp. 566-577. doi: 10.5658/WOOD.2015.43.5.566. 
- Halaman ini sengaja dikosongkan - 